\title{
Measurements of natural radioactivity in soil samples around Kufa cement factory sites in Najaf governorate, Iraq
}

\author{
L.A. Alasadi ${ }^{*}$, A.S. Alaboodi ${ }^{1}$, A.H. Alasadi², M.H. Al-Taweel ${ }^{1}$, \\ F.S. Abbas ${ }^{1}$
}

${ }^{1}$ Department of Physics, Faculty of Science, Kufa University, Iraq

${ }^{2}$ Department of Laboratory Investigations, Faculty of Science, Kufa University, Iraq

\section{- Original article}

*Corresponding author:
Lubna A. Alasadi, Ph.D.,
E-mail:
$\quad$ Lubna.alasadi@uokufa.edu.iq
Revised: July 2020
Accepted: September 2020
Int. J. Radiat. Res., October 2021;
19(4): 1035-1040
DOI: 10.29242/ijrr.19.4.1035

*Corresponding author:

Lubna A. Alasadi, Ph.D.,

-mail:

Revised: July 2020

Accepted: September 2020

Int. I. Radiat. Res., October 2021;

DOI: $10.29242 /$ ijrr.19.4.1035

\section{ABSTRACT}

Background: This research focuses on the study of ${ }^{40} \mathrm{~K},{ }^{238} \mathrm{U}$, and ${ }^{232} \mathrm{Th}$ in a specific area at Kufa Cement Factory Sites in Najaf Governorate, Iraq using the $\mathrm{y}$-ray spectrometry scintillation detector $\mathrm{Nal}(\mathrm{TI})$. Materials and Methods: Samples of soil were collected from locations around the Kufa cement factory in Najaf city of Iraq that are about $10 \mathrm{~km}^{2}$ away from the center of Najaf city. They were analyzed to set the concentrations of natural radioactivity samples of ${ }^{40} \mathrm{~K},{ }^{238} \mathrm{U}$ and ${ }^{232} \mathrm{Th}$. Results: The specific activity values of ${ }^{40} \mathrm{k},{ }^{238} \mathrm{U}$ and ${ }^{232} \mathrm{Th}$ varied from $(378.54 \pm 11.39$ to $2404.27 \pm 26.13) \mathrm{Bq} / \mathrm{kg},(15.51 \pm 5.88$ to $106.08 \pm 7.35) \mathrm{Bq} / \mathrm{kg}$ and $(1.80 \pm 3.41$ to78.19 \pm 3.05$) \mathrm{Bq} / \mathrm{kg}$ continually. Conclusions: Results demonstrate that the convergences of radiation and doses due to radionuclides in the overviewed area are higher than the safety field of the worldwide average (UNSCAER 2000). Almost all of the radiological parameters are inconsequential to cause any dangerous health problems to people living in the area.

Keywords: Natural radioactivity, gamma-ray spectroscopy, soil, Kufa cement factory.

\section{INTRODUCTION}

The contamination of metal for soil dust and rural soils emerging from vehicular discharges, mechanical exercises, and waste transfer destinations is very much reported. The most important part of industries is the cement industry which is famous to be problematic as from the dust exuding from their activities (1). Testimony for those follows metals that happened in different parts all over the bond production lines is affected by wind speed, molecule size, and stack exhaust (2). Cement is made of $25 \mathrm{mg} / \mathrm{kg} \mathrm{Cr}, 21 \mathrm{mg} / \mathrm{kg} \mathrm{Cu}, 20 \mathrm{mg} / \mathrm{kg}$ $\mathrm{Pb}$, and $53 \mathrm{mg} / \mathrm{kg} \mathrm{Zn}(3,4)$. Past examinations in different nations had shown that dust contained lifted measures of metals exuding from the region of concrete production lines may unfavorably influence people, such as soil and plants created in the area (5-7). Generally speaking, over the top dimensions of overwhelming metals may be as a result of oxidation push, harm to DNA (8). Therefore; periodic inspections must be conducted periodically for informing the population about the health effects of the factories' waste.

There are many types of research that have dealt with the study of natural radioactivity in surface soils in Najaf city, Iraq (9-13). The results from these studies have shown that there are no important levels of radionuclides in the environment. Kufa and Najaf cement factories are together in one place outside the city.

The aim of this study, showing that the specific activities of ${ }^{238} \mathrm{U},{ }^{232} \mathrm{Th}$, and ${ }^{40} \mathrm{~K}$, as well as the radiological parameters such as absorbed dose rate (AD), radium equivalent activity $\left(\mathrm{Ra}_{\mathrm{eq}}\right)$, external hazard index $\left(\mathrm{H}_{\mathrm{ex}}\right)$ and internal hazard index $\left(\mathrm{H}_{\text {in }}\right)$, were evaluated in the soil samples around Kufa /Najaf cement in Iraq using NaI(Tl) 
detector.

\section{MATERIALS AND METHODS}

\section{Area of study}

Kufa Cement Factory is located at $44^{\circ}$ $26^{\prime} 26.42^{\prime \prime}$ E longitude, $31^{\circ} 58^{\prime} 11.61^{\prime \prime} \mathrm{N}$ latitude) in the south of Najaf city. The present investigation area surveyed was divided according to the deliberate determination as radial distribution with sampling locations. The samples of soil were collected in an area of approximately 12.56 $\mathrm{km}^{2}$ around the Kufa cement factory in Najaf city in Iraq as in figure 1. Total circuits around the factory were four circuits. The dimension between each circuit and the other was one kilometer. Google earth program was used to obtain the geographic location by the upper view of the studied area. Situations of samples were determined by using (GPS).

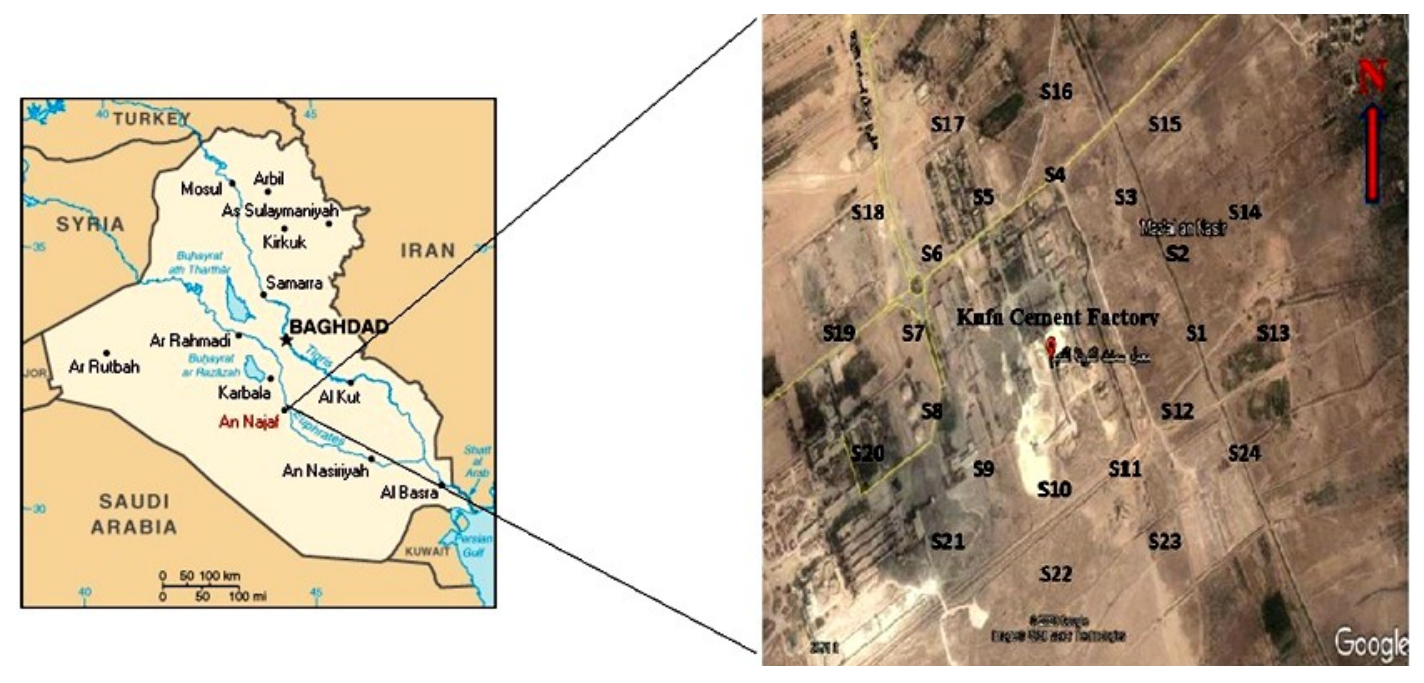

\section{Sampling and sample analysis}

Samples of soil were collected from the locations around the Kufa cement factory in Najaf city of Iraq that is about $10 \mathrm{~km}^{2}$ away from the center of Najaf city $\left(31^{05748.20 N}\right.$ and $44^{0} 2612.60 \mathrm{E}$ ). Soil tests were gathered utilizing a coring instrument around the territory. The cross (composite) technique for testing was utilized. The center profundity was in the range somewhere of $(0-50) \mathrm{cm}$. Soil samples were traded to waterproof nylon packs and then taken to the nuclear laboratory at the University of Kufa, department of physics for examination. The sum of 48 tests was gathered together.

About $500 \mathrm{gm}$ of each soil sample was examined. An oven-dried (LG, Korea) was used for the samples, which included "surface grasses and crushed to pass $0.8 \mathrm{~mm}$-mesh sieve". A liter Marinelli container was used to sieve samples and they were saved for a period of three weeks for "equilibration prior to $\gamma$ - spectroscopy".
Time was counted for each sample to $(18000$ sec). The spectrometer was balanced for essentialness by getting a range from four standard wellsprings of gamma radiations. These sources were ${ }^{22} \mathrm{Na},{ }^{60} \mathrm{Co},{ }^{54} \mathrm{Mn}$, and ${ }^{137} \mathrm{Cs}$ (14).

\section{Calculating the specific activity and the radiological hazard}

The specific activities of ${ }^{238} \mathrm{U},{ }^{232} \mathrm{Th}$, and ${ }^{40} \mathrm{~K}$, as well as the radiological parameters such as radium equivalent activity ( $(\mathrm{Ra}$ eq), absorbed dose rate (AD), external hazard index $\left(\mathrm{H}_{\mathrm{ex}}\right)$ and internal hazard index $\left(\mathrm{H}_{\text {in }}\right)$, were calculated as in equation (1) (9-13):

$$
\mathrm{A}(\mathrm{Bq} / \mathrm{kg})=\frac{\mathrm{N}}{\mathrm{t} \times \varepsilon \times \mathrm{I}_{Y} \times \mathrm{m}}
$$

where $\mathrm{N}$ net area under photopeak, $\mathrm{t}$ is the counting time (sec), $\mathrm{I}_{\gamma}$ the gamma emission probability, $m$ the sample weight $(\mathrm{kg}), \varepsilon$ the 
absolute efficiency of the detector at particular gamma energy. to calculate the specific activities for ${ }^{238} \mathrm{U},{ }^{232} \mathrm{Th}$ and ${ }^{40} \mathrm{~K}$, equations $2-5$ were used:

$\mathrm{Ra}_{\mathrm{eq}}(\mathrm{Bq} / \mathrm{kg})=\mathrm{A}_{\mathrm{Ra}}+1.43 \mathrm{~A}_{\mathrm{Th}}+0.077 \mathrm{~A}_{\mathrm{K}}$

$\mathrm{AD}(\mathrm{nGy} / \mathrm{h})=0.462 \mathrm{~A}_{U}+0.604 \mathrm{~A}_{\mathrm{Th}}+0.0417 \mathrm{~A}_{\mathrm{K}}(3)$

$\mathrm{H}_{\mathrm{ex}}=\frac{\mathrm{A}_{\mathrm{Ra}}}{370}+\frac{\mathrm{A}_{\mathrm{Th}}}{258}+\frac{\mathrm{A}_{\mathrm{K}}}{4810}$

$\mathrm{H}_{\text {in }}=\frac{\text { ARa }}{185}+\frac{\text { ATh }}{259}+\frac{\text { AK }}{4810}$

Where, $A_{R a}, A_{T h}$ and $A_{K}$ were the specific activities for ${ }^{238} \mathrm{U},{ }^{232} \mathrm{Th}$, and ${ }^{40} \mathrm{~K}$ respectively to find an equivalent activity $\left(\mathrm{Ra}_{\mathrm{eq}}\right)$, absorbed dose rate (AD), external hazard index $\left(\mathrm{H}_{\mathrm{ex}}\right)$ and internal hazard index $\left(\mathrm{H}_{\mathrm{in}}\right)$.

\section{Statistical analysis}

The strategy for gamma-beam glimmer spectrometer is utilized in the assurance of the regular radionuclide fixations in the dirt examples. $\mathrm{NaI}(\mathrm{Tl})$ was used, which contained a scintillation detector $\mathrm{NaI}(\mathrm{Tl})$ of $(3 " \times 3 ")$ crystal dimension, supplied by (Alpha Spectra, Inc.-12I12/3), coupled with a multi-channel analyzer (MCA) (ORTEC -Digi Base) with a range of 4096 channel joined with ADC (Analog to Digital Converter) unit, through an interface. Finally, the collected data were directly converted to the PC of the laboratory introduced using (Maestro-32) software. The results with graphing were statistically analyzed and results obtained using programs like M.S. Excel and Minitab 17 for windows 7.

\section{RESULTS}

The specific activity values of ${ }^{238} \mathrm{U},{ }^{232} \mathrm{Th}$, and ${ }^{40} \mathrm{~K}$ radionuclides and Radium equivalent for 24 soil samples were tabulated in table 1 .

Table 1 shows that the min. value of specific activity for ${ }^{238} \mathrm{U}$ was $15.51 \pm 5.88 \mathrm{~Bq} / \mathrm{kg}$ registered in a soil sample $\left(\mathrm{S}_{4}\right)$, and the Max. The value of specific activity for ${ }^{238} \mathrm{U}$ was $106.08 \pm 7.35 \mathrm{~Bq} / \mathrm{kg}$ registered in a soil sample

Int. J. Radiat. Res., Vol. 19 No. 4, October 2021
$\left(\mathrm{S}_{17}\right)$. An average value was $58.80 \pm 6.22 \mathrm{~Bq} / \mathrm{kg}$ and it also showed that the specific activity in $\mathrm{Bq} / \mathrm{kg}$ of $232 \mathrm{Th}$ in the range of $01.80 \pm 3.41$ to $78.19 \pm 3.05 \mathrm{~Bq} / \mathrm{kg}$ with an average of 42 . $38 \pm 3.20 \mathrm{~Bq} / \mathrm{kg}$. The min. value was in the sample $\left(\mathrm{S}_{13}\right)$ and a Max. The value was in the sample $\left(\mathrm{S}_{2}\right)$.

The table above has also been explained the specific activity for ${ }^{40} \mathrm{~K}$ which was $652.22 \pm 10.60$ $\mathrm{Bq} / \mathrm{kg}$ registered in a soil sample $\left(\mathrm{S}_{10}\right)$, and the Max. The value of the specific activity for ${ }^{40} \mathrm{~K}$ was $2404.27 \pm 26.13 \mathrm{~Bq} / \mathrm{kg}$ registered in the soil sample $\left(\mathrm{S}_{15}\right)$.

The Radium equivalent activity of 24 soil samples was also calculated in the same table above. Raeq. Values vary from 117.46 to 360.98 $\mathrm{Bq} / \mathrm{kg}$ with an average value of $198.37 \mathrm{~Bq} / \mathrm{kg}$.

Radiation risk factors such as $\mathrm{AD}, \mathrm{H}_{\mathrm{ex}}, \mathrm{H}_{\text {in }}$ and (I $\gamma$ ) were also measured and scheduled for 48 soil samples (table 2 ).

Table 1. Radium equivalent in ( $\mathrm{Bq} / \mathrm{kg})$ and Specific Activity for soil samples.

\begin{tabular}{|c|c|c|c|c|}
\hline \multirow{2}{*}{$\begin{array}{c}\text { Sample } \\
\text { code }\end{array}$} & \multicolumn{3}{|c|}{ Specific activity (Bq/kg) } & $\begin{array}{c}\text { Ra } \\
\text { (Bq }\end{array}$ \\
\hline S1 & $25.60 \pm 05.57$ & $32.04 \pm 3.11$ & $1110.68 \pm 18.79$ & 156.93 \\
\hline S2 & $76.05 \pm 06.59$ & $78.19 \pm 3.05$ & $1315.07 \pm 17.41$ & 289.12 \\
\hline S3 & $46.85 \pm 07.03$ & $34.44 \pm 3.54$ & $763.84 \pm 11.71$ & 154.91 \\
\hline S4 & $15.51 \pm 05.88$ & $41.79 \pm 3.31$ & $1032.17 \pm 17.59$ & 154.75 \\
\hline S5 & $51.90 \pm 7.52$ & $28.24 \pm 2.73$ & $734.09 \pm 14.55$ & 148.81 \\
\hline S6 & $62.54 \pm 6.07$ & $25.48 \pm 2.53$ & $661.58 \pm 13.62$ & 149.91 \\
\hline S7 & $26.86 \pm 05.81$ & $40.55 \pm 2.64$ & $792.55 \pm 14.22$ & 145.88 \\
\hline S8 & $55.24 \pm 06.99$ & $46.67 \pm 4.02$ & $908.27 \pm 18.63$ & 191.91 \\
\hline S9 & $48.77 \pm 05.93$ & $32.45 \pm 2.44$ & $688.24 \pm 15.68$ & 148.17 \\
\hline S10 & $30.40 \pm 04.31$ & $26.12 \pm 1.88$ & $652.22 \pm 10.60$ & 117.98 \\
\hline S11 & $61.69 \pm 07.07$ & $64.28 \pm 4.06$ & $1251.41 \pm 20.07$ & 249.97 \\
\hline S12 & $64.43 \pm 03.78$ & $41.90 \pm 1.94$ & $778.27 \pm 12.69$ & 184.27 \\
\hline S13 & $86.63 \pm 07.07$ & $1.80 \pm 3.41$ & $1170.66 \pm 19.70$ & 179.35 \\
\hline S14 & $82.03 \pm 08.54$ & $58.05 \pm 4.98$ & $1360.36 \pm 22.55$ & 269.79 \\
\hline S15 & $86.73 \pm 06.41$ & $62.32 \pm 4.30$ & $2404.27 \pm 26.13$ & 360.98 \\
\hline S16 & $39.41 \pm 04.99$ & $42.72 \pm 2.93$ & $804.94 \pm 13.04$ & 162.49 \\
\hline S17 & $106.08 \pm 07.35$ & $45.91 \pm 2.47$ & $692.65 \pm 15.41$ & 225.07 \\
\hline S18 & $60.25 \pm 4.47$ & $62.06 \pm 2.00$ & $971.82 \pm 13.71$ & 223.82 \\
\hline S19 & $44.56 \pm 5.28$ & $45.75 \pm 3.97$ & $807.55 \pm 22.71$ & 172.17 \\
\hline S20 & $63.79 \pm 06.47$ & $50.79 \pm 2.34$ & $1149.19 \pm 14.67$ & 224.92 \\
\hline S21 & $46.66 \pm 06.41$ & $44.18 \pm 4.12$ & $1134.53 \pm 18.97$ & 197.20 \\
\hline S22 & $27.57 \pm 05.26$ & $30.48 \pm 3.06$ & $711.57 \pm 18.04$ & 125.94 \\
\hline S23 & $99.29 \pm 7.00$ & $37.08 \pm 3.94$ & $1505.28 \pm 14.59$ & 268.22 \\
\hline S24 & $102.37 \pm 07.71$ & $44.05 \pm 4.24$ & $1207.25 \pm 22.12$ & 258.32 \\
\hline Min. & $15.51 \pm 05.88$ & $1.80 \pm 3.41$ & $652.22 \pm 10.60$ & 117.46 \\
\hline Max. & $106.08 \pm 07.35$ & $78.19 \pm 3.05$ & $2404.27 \pm 26.13$ & 360.98 \\
\hline Average & $58.80 \pm 6.22$ & $42.38 \pm 3.20$ & $1025.35 \pm 16.96$ & 198.37 \\
\hline & & & & 1 \\
\hline & & & & \\
\hline
\end{tabular}


Table 2. Absorbed dose rate, External and Internal hazard Indexes, and activity concentration Index (I $/$ ) of soil samples.

\begin{tabular}{|c|c|c|c|c|}
\hline Sample code & AD (nGy/h) & $\mathrm{H}_{\mathrm{ex}}$ & $\mathbf{H}_{\text {in. }}$ & $I_{\gamma}$ \\
\hline $\mathrm{S} 1$ & 78.04 & 0.42 & 0.49 & 0.62 \\
\hline S2 & 138.53 & 0.78 & 0.99 & 1.08 \\
\hline S3 & 74.88 & 0.42 & 0.55 & 0.58 \\
\hline S4 & 76.16 & 0.42 & 0.46 & 0.60 \\
\hline S5 & 72.13 & 0.40 & 0.54 & 0.56 \\
\hline S6 & 72.3 & 0.40 & 0.57 & 0.56 \\
\hline S7 & 70.64 & 0.39 & 0.47 & 0.56 \\
\hline $\mathrm{S} 8$ & 92.38 & 0.52 & 0.67 & 0.72 \\
\hline S9 & 71.38 & 0.4 & 0.53 & 0.55 \\
\hline S10 & 57.46 & 0.32 & 0.4 & 0.45 \\
\hline S11 & 120.60 & 0.68 & 0.84 & 0.94 \\
\hline S12 & 88.24 & 0.5 & 0.67 & 0.68 \\
\hline S13 & 89.96 & 0.48 & 0.72 & 0.69 \\
\hline S14 & 130.67 & 0.73 & 0.95 & 1.02 \\
\hline S15 & 179.03 & 0.97 & 1.21 & 1.40 \\
\hline S16 & 78.31 & 0.44 & 0.55 & 0.61 \\
\hline S17 & 106.40 & 0.61 & 0.89 & 0.81 \\
\hline S18 & 106.90 & 0.6 & 0.77 & 0.84 \\
\hline S19 & 82.67 & 0.46 & 0.59 & 0.65 \\
\hline S20 & 108.94 & 0.61 & 0.78 & 0.85 \\
\hline S21 & 96.30 & 0.53 & 0.66 & 0.75 \\
\hline S22 & 61.33 & 0.34 & 0.41 & 0.48 \\
\hline S23 & 131.67 & 0.72 & 0.99 & 1.02 \\
\hline S24 & 124.99 & 0.7 & 0.97 & 0.96 \\
\hline Min. & 57.46 & 0.32 & 0.4 & 0.45 \\
\hline Max. & 179.03 & 0.97 & 1.21 & 1.40 \\
\hline Average & 94.37 & 0.53 & 0.69 & 0.73 \\
\hline
\end{tabular}

Table 2 shows that the minimum value of $A D$ was $57.46 \mathrm{nGy} / \mathrm{h}$ registered in a soil sample $\left(\mathrm{S}_{10}\right)$, and the maximum the value was 179.03 $\mathrm{nGy} / \mathrm{h}$ registered in the soil sample $\left(\mathrm{S}_{15}\right)$. An average value was $94.37 \mathrm{nGy} / \mathrm{h}$.

Table 2 also shows the values of $\mathrm{H}_{\text {ex }}$ and $\mathrm{H}_{\text {in }}$. of the soil samples. The values have been found to lie in the range of 0.32 to $0.97 \mathrm{~Bq} / \mathrm{kg}$ with an average of $0.53 \mathrm{~Bq} / \mathrm{kg}$, and from 0.4 to $1.21 \mathrm{~Bq} /$ $\mathrm{kg}$ with an average value of $0.69 \mathrm{~Bq} / \mathrm{kg}$ for $\mathrm{H}_{\mathrm{ex}}$.

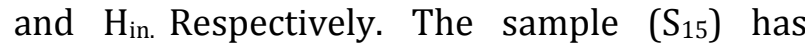
registered maximum value for each of $\mathrm{H}_{\mathrm{ex}}$ and $H_{\text {in., }}$ while the sample $\left(S_{10}\right)$ has registered the min. value for each of $\mathrm{H}_{\mathrm{ex}}$ and $\mathrm{H}_{\text {in }}$ respectively.

For the estimation of the danger due to gamma radiation related to the natural radionuclides ${ }^{238} \mathrm{U},{ }^{232} \mathrm{Th}$, and ${ }^{40} \mathrm{~K}$, in the study matter, $\mathrm{I}_{\gamma}$ was calculated and listed in table 2 . The min. value of Activity concentration index $\mathrm{I}_{\gamma}$ was $0.45 \mathrm{~Bq} / \mathrm{kg}$ fixed in a soil sample (S10), and the maximum value of the activity concentration index I $\gamma$ was $1.40 \mathrm{~Bq} / \mathrm{kg}$ fixed in the soil sample (S15). The average value was $0.73 \mathrm{~Bq} / \mathrm{kg}$. Figures 2 and 3 show $\left(\mathrm{I}_{\gamma}\right)$ and (AD) in all samples understudy with the permissible limit.

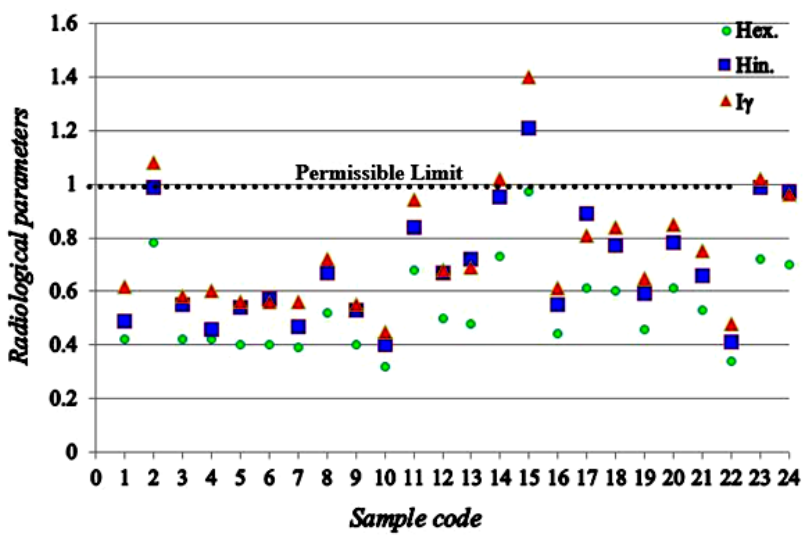

Figure 2. Relation between Radiological hazards with world limit.

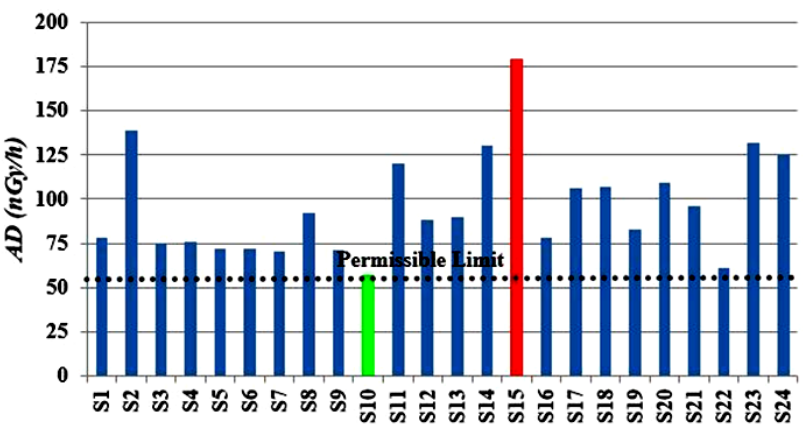

Sample code

Figure 3. Relation between $A D$ with world limit.

\section{DISCUSSION}

The obtained values of ${ }^{238} \mathrm{U}$ and ${ }^{232} \mathrm{Th}$ nuclides are comparable to the worldwide average specific activity of these radionuclides in soil reported by the (UNSCEAR 2000 report) which are $35 \mathrm{~Bq} / \mathrm{kg}$ for ${ }^{238} \mathrm{U}$ and $30 \mathrm{~Bq} / \mathrm{kg}$ for ${ }^{232} \mathrm{Th}$. Then, the averages specific activity of 24 soil samples are out of the range of worldwide average (15). An average value was $1025.35 \pm 16.96 \mathrm{~Bq} / \mathrm{kg}$, by comparison, an average value with the worldwide average specific activity of these radionuclides in soil reported by the UNSCEAR 2000 report which is $400 \mathrm{~Bq} / \mathrm{kg}$ for ${ }^{40} \mathrm{~K}$ (15). So, in this work the

Int. J. Radiat. Res., Vol. 19 No. 4, October 2021 
average specific activity obtained is higher than the average value of worldwide and this leads to a high specific activity of this radionuclide for all soil samples which means higher than the permissible level.

The specific activities of ${ }^{232} \mathrm{Th},{ }^{238} \mathrm{U}$, and ${ }^{40} \mathrm{k}$ have various values in each site in all the areas studied. This difference can be attributed to the circumstances of the geographical nature of each region, such as the soil type (sand or clay). The highest allowable concentration of the soil due to the increase in the concentration of potassium nuclide in some areas can be attributed to the existence of agricultural lands and areas consisting of phosphate fertilizers in which the focus is on the increasingly peer-potassium $\left({ }^{40} \mathrm{~K}\right)$.

It can be seen that the $\mathrm{Ra}_{\text {eq. }}$ Values for all soil samples were lower than the recommended Max. Value $370 \mathrm{~Bq} / \mathrm{kg}$ (15). All values of the absorbed dose rate of soil samples were higher than the limited values with factor $55 \mathrm{nGy} / \mathrm{h}(16$, 17). According to the results in table 2 , the averages of $\mathrm{H}_{\text {ex. }}$ and $\mathrm{H}_{\text {in. }}$ for all samples were less than unity which is the Max. Value of the permissible safety limit recommended by the United Nations Scientific Committee on the Effects of Atomic Radiation (UNSCEAR 2000) (18).When comparing the results of the average specific activity of elements ${ }^{238} \mathrm{U},{ }^{232} \mathrm{Th}$, and ${ }^{40} \mathrm{k}$ in the current study with the results recorded in different locations of Iraq (19-22), it is found that all results are larger than other previous studies. The increase or decrease of the recorded values is due to many factors such as the soil type, the geological nature of the area, the region selected (industrial or agricultural) or maybe exposure to other external factors.

\section{CONCLUSIONS}

It is recommended that to prevent the usage of chemical fertilizers as far as possible in the surrounded farmlands of the factory. It is important to reduce the separated dust coming from the operation of fabrication cement. It is also important to perform periodic measurements for monitoring the natural specific activity in the areas surrounding the factory. We recommend measuring the specific activity of each sample which is used in the fabrication of cement.

\section{Conflicts of interest: Declared none.}

\section{REFERENCES}

1. Arogunjo A (2004) Dose rate assessment of terrestrial gamma radiation in the Delta region of Nigeria. Radiation Protection Dosimetry, 108(1): 73-77.

2. Kant K, Upadhyay SB, Sonkawade RG, Chakarvarti SK (2006) Radiological risk assessment of use of phosphate fertilizers in the soil. Int J Radiat Res, 4(2): 63-70.

3. Cinar H, Altundaş S, _Çelik N, Maden N(2017) In situ gamma ray measurements for deciphering of radioactivity level in Sarıhan pluton area of northeastern Turkey. Arabian Journal of Geosciences, 10(19): 435.

4. Ajayi OS, Ibikunle SB, Ojo TJ (2008) An assessment of natural radioactivity of soils and its external radiological impact in southwestern Nigeria. Health Physics, 94(6): 558-566.

5. Farai I, Ojunakwe C, Makinde O (2007) Gamma spectroscopic assay of soil samples from waste dump sites in Port Harcourt, Nigeria. ICRM Conference. Cape Town, South Africa.

6. Florou H, Trabidou G, Nicolaou G (2007) An assessment of the external radiological impact in areas of Greece with elevated natural radioactivity. Journal of Environmental Radioactivity, 93(2): 74-83.

7. Malanca A, Gaidolfi L, Pessina V, Dallara G (1996) Distribution of 226Ra, 232Th, and 40K in soils of Rio Grande do Norte (Brazil). Journal of Environmental Radioactivity, 30 (1): 55-67.

8. Myrick T, Berven B, Haywood F (1983) Determination of concentrations of selected radionuclides in surface soil in the U.S. Health Physics, 45(3): 631-642.

9. Almayahi B (2014) Gamma spectroscopic of soil samples from Kufa in Najaf governorate, Iraq. World Applied Sciences, 31(9): 1582-1588.

10. Makki F, Kadhim NAS, Alasadi A, Almayahi B (2014) Natural radioactivity measurements in different regions in Najaf city, Iraq. International Journal of Computer Trends and Technology, 9(6): 286-289.

11. Hussain RO (2014) Measurement of natural radioactivity in the Soil of Kufa city-Iraq. Arabic and English Journal of Kufa -physics, 6(2): 45-57.

12. Mirza AA, Al-Gazaly HH, Abojassim AA (2017) Radioactivity levels and radiological risk assessment in soil samples of Nasiriyah thermal power station, Iraq. International Journal of Engineering Technology Science and Research, 4(6): 
1-7.

13. Alaboodi AA, Kadhim NA, Abojassim AA, Hassan AB (2020) Radiological hazards due to natural radioactivity and radon concentrations in water samples at Al-Hurrah city, Iraq. Int J Radiat Res, 18(1): 1-11.

14. Almayahi BA (2015) Nal (TI) spectrometry to natural radioactivity measurements of soil samples in Najaf city. Iranica Journal of Energy and Environment, 6(3): 207-211.

15. United Nations (2000) Scientific Committee on the Effects of Atomic Radiation. Sources and effects of ionizing radiation: sources (Vol. 1). United Nations Publications.

16. United Nations (2000) Scientific Committee on the Effects of Atomic Radiation. Sources and effects of ionizing radiation: sources (Vol. 2). United Nations Publications.

17. ICRP (International Commission on Radiological Protection) (1993) Report 62. Radiological protection in biomedical research, Pergamon Press, Oxford.

18. Mika M (1995) Radiation dose assessments for materials with elevated natural radioactivity. Finnish centre for radiation and nuclear safety; STUK-B-STO 32, Poland.

19. Abojassim AA (2017) Estimation of human radiation exposure from natural radioactivity and radon concentrations in soil samples at green zone in Al-Najaf, Iraq. Iranian Journal of Energy and Environment 8(3): 239-248.

20. Yousif SAR, Abojassim AA, Hayder A (2019) Mapping of natural radioactivity in soil samples of Badra oil field project using GIS program. Nuclear Physics and Atomic Energy, 20(1): 60-69.

21. Abojassim AA and Rasheed LH (2019) Mapping of terrestrial gamma radiation in soil samples at Baghdad governorate (Karakh side) using GIS technology. Nature Environment \& Pollution Technology, 18(4): 1095-1106.

22. Majeed FA, Abojassim AA, Ali AM (2019) Radiological risk due to naturally occurring radioactive materials in the soil of Al-Samawah desert, Al-Muthanna governorate, Iraq. Iranian Journal of Medical Physics, 16(5): 323-328. 